\title{
THE BREEDING OF ARENICOLA ECAUDATA JOHNSTON AND $A$. BRANCHIALIS AUD. \& EDW. AT PLYMOUTH
}

\author{
By Eve C. AND A. J. Southward \\ The Plymouth Laboratory
}

(Text-figs. I-9)

The two 'tail-less' lugworms, Arenicola ecaudata Johnston and A. branchialis Audouin and Milne-Edwards ( $=$ A. grubii Claparède), live in gravel and under stones, unlike the 'tailed' species which are found mainly in sandy beaches. Both are local in distribution compared with the wide-spread caudate species. A. ecaudata is known to occur from Iceland to northern Spain, and thus has a rather more boreal distribution than $A$. branchialis which ranges from the west coast of Scotland to Morocco, the Mediterranean and the Black Sea. (Ashworth, 1912; McIntosh, 1915; Fauvel, 1927; Rioja, 1935; WesenbergLund, 195I.) Neither species is known from the western side of the Atlantic.

Since the two species can often occur side by side and it appeared that they were adapted, not for life in different habitats, but for different temperature régimes, it was suggested to us by Prof. G. P. Wells, F.R.S., that an investigation of their breeding seasons at Plymouth might help in understanding their distribution and specific separation. It happened that we had already made some preliminary investigations in the Isle of Man, and we were therefore pleased to adopt Prof. Wells's suggestion.

Mature specimens of both species have been noted by previous workers. Ashworth (1912) found mature gametes in A. ecaudata at Port Erin in April and at Plymouth in August. Fauvel (I899) recorded mature worms at Cherbourg from March to October, while Hentschel (1930) believed spawning occurred at Plymouth in February-March and August-September. It thus seemed possible that $A$. ecaudata spawned during the warmer half of the year. A. branchialis, on the other hand, was considered to be mature in SeptemberOctober in Britain (Ashworth, 1912) and in winter at Naples (Lo Bianco, 1909). Samples of both species examined by ourselves at Port Erin showed no such difference in periods of maturity. Apparently mature gametes of $A$. ecaudata were found during the winter and of $A$. branchialis in the spring. It was therefore clear that it might be necessary to sample both species for more than a year to determine the breeding period with certainty.

The work at Plymouth has confirmed that both species may be breeding at the same time, but has shown significant differences in the breeding cycle. The 
results help to explain certain aspects of the behaviour, development and systematics of the species.

We are indebted to Prof. G. P. Wells for ideas on which the work was based, and for encouragement and advice. One of us was in receipt of a D.S.I.R. senior research award during part of the work.

\section{MATERIAL}

A. ecaudata and A. branchialis are fairly common on most shores around Plymouth, in gravel or sandy gravel under stones. According to Fauvel (I927) the distribution of these species on the shore, in France, is as follows: A. ecaudata is found 'à un niveau assez bas', while $A$. branchialis lives 'jusqu'à un niveau découvrant à toutes les marées. A un niveau plus bas elle est souvent mélangée à $A$. ecaudata.'

Some of our samples were collected at Drake's Island, in Plymouth Sound, by $\mathrm{Mr}$ A. C. Briggs, but most of the material used was collected by the authors at Wembury Beach. Here a small sandy beach separates two masses of rock, Church Reef and West Reef, each with numerous gullies filled with gravel and boulders. The two species of Arenicola occur together in these gullies, from about mid-tide level to extreme low water mark. Between October 1955 and August 1956 we kept separate our samples from different tide levels. On Church Reef 201 worms were collected between L.W.S. and L.w.N.; of these I 77 were ecaudata and 24 branchialis. Between L.W.N. and M.T.L. the total was 210, of which only 97 were ecaudata. The L.W.S. to L.W.N. level of the West Reef produced a total of 244 worms, including 197 ecaudata. These results agree in the main with Fauvel, except that ecaudata was found mixed with branchialis at all levels, not only towards low water.

Although the figures suggest that there were about equal numbers of the two species between L.W.N. and M.T.L., branchialis retreats rapidly into its burrow and more were present in the gravel than were collected in our samples. Thus branchialis may form rather more than $50 \%$ of the population above L.W.N. Above M.T.L. and below M.L.W.S. we found a few specimens of both species, but in too small a number to determine the real proportions.

Apart from this difference in abundance with tide level, we noted that at all inhabited levels $A$. branchialis was the commoner in patches of sandy gravel which were more exposed to wave action, while A. ecaudata was often found alone in sheltered hollows where the gravel contained much sea-weed debris and decaying organic matter. However, both species have been found at wave beaten places such as Rame Head, where they occur side by side in gullies of coarse gravel; both species can also be found in places where the 'black layer' (Bruce, 1928) lies close to the surface. There thus seems to be no constant correlation with type of deposit or organic content in either species. When both species are considered together and compared with the only other species of 
Arenicola present in the British Isles (A. marina L.) there is a clear separation of habitats. At Plymouth and the Isle of Man we have found A. marina together with either of the other species only twice in samples totalling over 2000 worms.

\section{METHODS}

The investigations began in May 1954 and sampling was continued at irregular intervals through 1954 and I955. Experience gained from these samples enabled a more regular series of samples, from November I955 to January I957, to be sexed and classified with greater accuracy. The samples were collected during spring tides, at monthly or fortnightly intervals during this period.

We planned to examine between twelve and twenty specimens of each species at a time, but owing to the irregular nature of the habitat, and the variable proportions of the species, some samples contained fewer than twelve specimens of each. We have omitted from our results samples of less than ten A. ecaudata and less than seven $A$. branchialis. The latter was always more difficult to find and it was necessary to search the same areas each time. However, there was no marked decline in abundance, and it is assumed that the vacant niches were filled up by migration of worms from surrounding areas.

In the laboratory the worms were first cleaned of gravel and mucus and sorted into species. For this purpose we relied on the differences in the number of abranchiate setigerous segments (Fauvel, 1927).

In the second series of samples the size of each worm was measured as volume (to the nearest $0.1 \mathrm{ml}$.) of sea water displaced, but this was not done before November 1955 .

Measurement of volume was followed by an examination of a drop of coelomic fluid from each worm.

In $A$. ecaudata most of the development of the gametes takes place in the gonads and the sex-products do not appear in the coelomic fluid until they are nearly mature. Thus, in this species, if the coelomic fluid contained no gametes the gonads were examined, and one of them removed for measurement of the oocytes. Our ability to sex immature and spent specimens of $A$. ecaudata increased during the survey, and this probably accounts for the absence of worms of unknown sex from the 1956 samples.

In $A$. branchialis the gonads are very small (see Fauvel, I927; Downing, I909, I9I I) and the gametes undergo most of their development in the coelom. It was therefore a simple matter to sex and classify this species by examining some of the coelomic fluid under the microscope.

Males and females were grouped into the developmental stages shown in Table $\mathrm{I}$, and the largest oocytes were measured with an eye-piece micrometer. The divisions of this micrometer ( $17 \mu$ with $\frac{2}{3}$ in. objective) were used to define 
the eleven oocyte stages in this species and the ten stages in A. ecaudata (see Table 2). In both species the oocytes are slightly oval in shape and the greatest diameter was measured.

\section{TABLE 1. DEFINITIONS OF BREEDING STAGES}

\begin{tabular}{|c|c|c|}
\hline \multirow{3}{*}{ Male } & \multicolumn{2}{|c|}{ Arenicola ecaudata } \\
\hline & Empty (E) & $\begin{array}{l}\text { Sex determinable from shape of gonads, no sex pro- } \\
\text { ducts visible in gonads or coelom }\end{array}$ \\
\hline & $\begin{array}{l}\text { Developing (D) } \\
\text { Mature (M) } \\
\text { Spent (S) }\end{array}$ & $\begin{array}{l}\text { Sex products in gonads, none in coelom } \\
\text { Coelom full of tailed sperm plates or free spermatozoa } \\
\text { A few sperm plates or spermatozoa in coelom, gonads } \\
\text { empty }\end{array}$ \\
\hline \multirow[t]{5}{*}{ Female } & Empty $(\mathrm{E})$ & As male \\
\hline & $\begin{array}{l}\text { Developing } \\
\text { (I) in gonads } \\
\text { (Dg) }\end{array}$ & Oocytes developing inside gonads, none in coelom \\
\hline & $\begin{array}{l}\text { (2) in coelom } \\
\text { (Dc) }\end{array}$ & $\begin{array}{l}\text { Coelom contains oocytes, of which less than } 90 \% \\
\text { have reached } 0.17 \mathrm{~mm} \text { in diameter } \\
\text { Coelom full of oocytes, of which at least } 90 \% \text { are }\end{array}$ \\
\hline & Mature $(M)$ & $0.17 \mathrm{~mm}$ or more in diameter \\
\hline & Spent $(\mathrm{S})$ & $\begin{array}{l}\text { Gonads still large but empty of oocytes, occasionally a } \\
\text { few large oocytes in the coelom }\end{array}$ \\
\hline Sex unknown & Empty (E) & Gonads very small or absent, no sex products visible \\
\hline \multicolumn{3}{|c|}{ Arenicola branchialis } \\
\hline Male & Developing (D) & $\begin{array}{l}\text { Coelom contains sperm mor } \\
\text { of which less than } 90 \% \text { ar }\end{array}$ \\
\hline \multirow{5}{*}{ Female } & Mature $(M)$ & $\begin{array}{l}\text { Coelom contains sperm discs of which at least } 90 \% \\
\text { are tailed }\end{array}$ \\
\hline & Spent (S) & A few tailed discs or spermatozoa in the coelom \\
\hline & Developing & $\begin{array}{l}\text { Coelom contains oocytes, of which less than } 90 \% \\
\text { have reached } 0.17 \mathrm{~mm} \text { in diameter }\end{array}$ \\
\hline & Mature $(M)$ & $\begin{array}{l}\text { Coelom full of oocytes, of which at least } 90 \% \text { have } \\
\text { reached } 0.17 \mathrm{~mm} \text { or more in diameter }\end{array}$ \\
\hline & Spent ( & $\begin{array}{l}\text { Coelom contains a few large oocytes, with often a few } \\
\text { very small }\end{array}$ \\
\hline Sex unknown & Empty (E) & No sex products discernible \\
\hline
\end{tabular}

TABLE 2. DEFINITION OF OOCYTE SIZE-GROUPS

\begin{tabular}{|c|c|c|c|}
\hline Group & $\begin{array}{l}\text { Diameter of largest } \\
\text { oocyte present }\end{array}$ & Group & $\begin{array}{l}\text { Diameter of largest } \\
\text { oocyte present }\end{array}$ \\
\hline o & $\begin{array}{l}\text { Ovary distinct but } \\
\text { no oocytes visible }\end{array}$ & 6 & $0.086-0.102 \mathrm{~mm}$ \\
\hline I & $\mathrm{Up}$ to $0.017 \mathrm{~mm}$ & 7 & $0.103-0.119 \mathrm{~mm}$ \\
\hline 2 & $0.018-0.034 \mathrm{~mm}$ & 8 & $0.120-0.136 \mathrm{~mm}$ \\
\hline 3 & $0.035-0.051 \mathrm{~mm}$ & 9 & $0.137-0.153 \mathrm{~mm}$ \\
\hline 4 & $0.052-0.068 \mathrm{~mm}$ & Io & $0.154-0.170 \mathrm{~mm}$ \\
\hline 5 & $0.069-0.085 \mathrm{~mm}$ & II & $0.17 \mathrm{I}-0.187 \mathrm{~mm}$ \\
\hline
\end{tabular}

\section{ARENICOLA BRANCHIALIS}

The sex of $A$. branchialis could not be determined from the gonads, so that when there were no sex products in the coelomic fluid the specimen was classified as 'of unknown sex'. The developing gametes, whether male or female, were shed from the gonads at an early stage in their development, and appeared in the coelomic fluid a few at a time over a period of months; gametes 
at all stages of development might be found in the coelom of one worm. After the production of gametes ceased maturation continued until all were full sized.

The development of sperm discs from balls of spermatogonia has been described by Downing (I9II) for several species of Arenicola, including branchialis. In the females the oocytes were shed from the ovaries at a diameter of $\mathrm{I} 7 \mu$ or even less. They grew steadily in size to a diameter of 0.17 $0.187 \mathrm{~mm}$ when mature. At a diameter of about $0.12 \mathrm{~mm}$ a thick vitelline membrane was formed. The mature oocytes have been described and figured by Ashworth (I9I2). After spawning, a few mature oocytes remained in the coelom of the female, often being mixed with the first small oocytes produced by the gonads as the cycle began again.
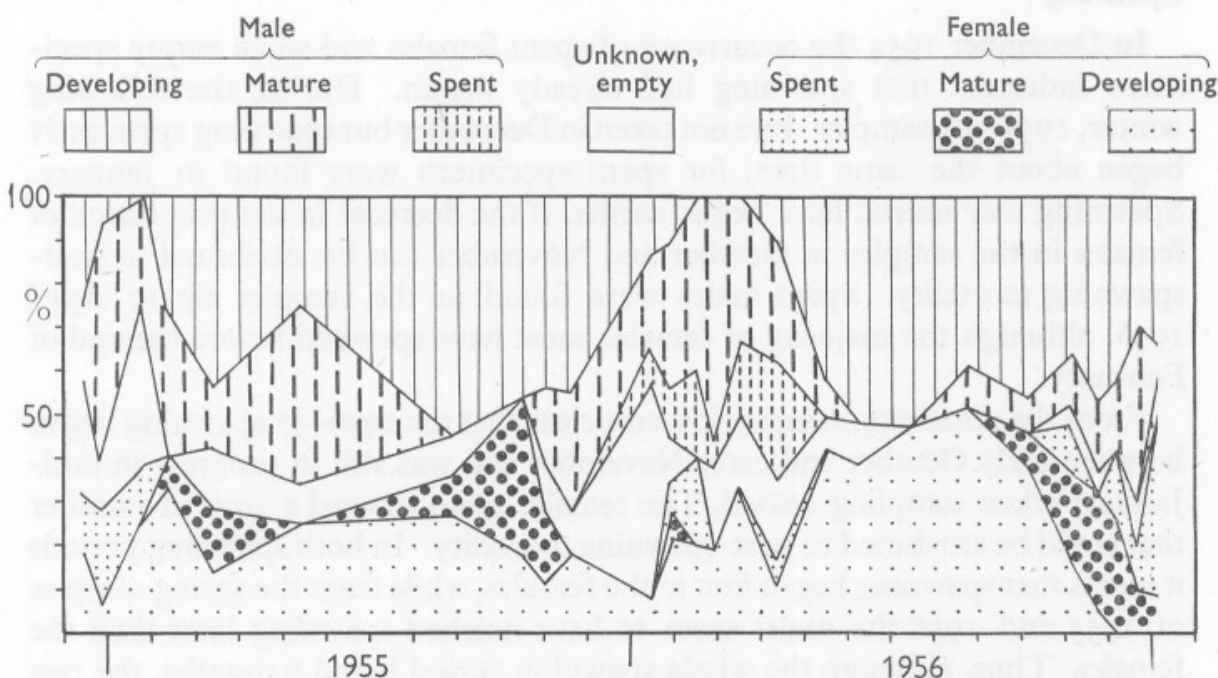

Fig. I. Arenicola branchialis. Percentages of breeding stages (see Table I) in samples from Wembury, December 1954 to January 1957.

\section{Annual cycle}

The results of 2 years' sampling are shown in Fig. I, the developmental stages being those of Table I. Samples were few in 1955 and included some small specimens; from 15 November 1955 specimens I ml. or under in volume have been omitted from the figure, since we believe that young specimens may develop at a different rate, and there seems to be a fairly steady recruitment of young specimens into the breeding population throughout the year.

The general pattern of development and spawning seems to have been the same in 1955 and 1956 . The gametes developed throughout the spring, summer and autumn, and spawning took place over a period of $4-6$ months centring 
on the winter. The 1954-55 spawning did not finish before the end of January, and may have gone on longer. Spent specimens were not found after the end of January, but mature females and males remained in the population until at least March and May, respectively. Development began again soon after spawning, while many individuals still had a few residual gametes in the coelom. Development of the females continued until the end of October 1955, when more than half of them were mature, though apparently all the males were still developing. Fig. 2 shows the development of the oocytes of the female population throughout 1955 and 1956 . Clearly, growth of oocytes continues slowly and steadily up to midsummer; thereafter, most of the population is mature for 3 or 4 months before spawning.

\section{Spawning}

In December 1954 the occurrence of spent females and some empty specimens indicated that spawning had already begun. During the following winter, 1955-56, samples were not taken in December but spawning apparently began about the same time, for spent specimens were found in January. Spawning may indeed have begun earlier, if the decrease in the proportion of females in the samples in October and November can be attributed to postspawning mortality. Spent males were found in the samples up to April 1956, although the majority of females must have spawned before the end of February.

From the remaining samples it seems clear that the 1956-57 spawning began between early October and early November and was still in progress in midJanuary when sampling ceased. The females again showed a drop in number that could be attributed to post-spawning mortality. In both spawning periods it seems that spawning began first in the females, while from the spring samples of 1955 and 1956 the males seem to have finished spawning later than the females. Thus, although the whole spawning period lasted 6 months, the two sexes apparently spawned together for only 4 months.

In $A$. branchialis, as in other species of Arenicola, spawning takes place through the nephridia and not through a breakdown of the body wall. Nevertheless, the sudden variations in the ratio of the sexes during the spawning season suggest that a number of worms of both sexes die after spawning, as in A. marina (Newell, 1948). We have not had spawning specimens of both sexes in the same sample, and have not seen naturally fertilized eggs, nor have any of our artificial fertilizations been successful. The larva remains unknown, but the post-larva has been described by Ashworth (I9I2); his specimens were collected in Ireland, among Laminaria roots, by Southern who also described them (1914). Post-larvae have not been recorded from the Plymouth area. The smallest specimens found by us among the gravel with the adults were 2-3 cm long and had all segments and branchiae. 


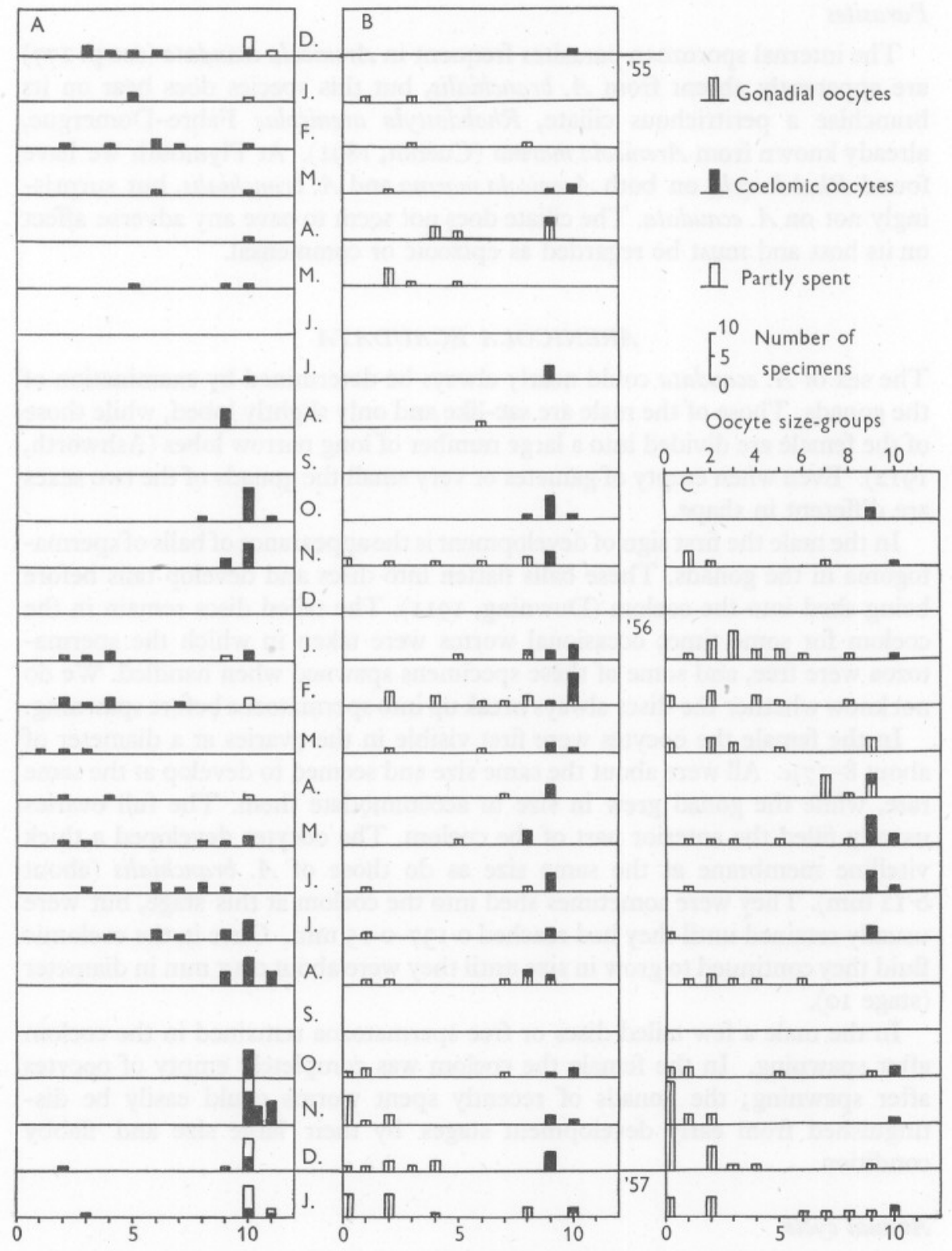

Fig. 2. Oocyte sizes. Number of worms containing oocytes of each size group (see Table 2), each month. A, Arenicola branchialis, Wembury; B, A. ecaudata, Church Reef, Wembury; c, A. ecaudata, West Reef, Wembury. 


\section{Parasites}

The internal sporozoan parasites frequent in Arenicola ecaudata (see p. 277) are apparently absent from $A$. branchialis, but this species does bear on its branchiae a peritrichous ciliate, Rhabdostyla arenicolae Fabre-Domergue, already known from Arenicola marina (Cuénot, I89I). At Plymouth we have found Rhabdostyla on both Arenicola marina and A. branchialis, but surprisingly not on $A$. ecaudata. The ciliate does not seem to have any adverse affect on its host and must be regarded as epizooic or commensal.

\section{ARENICOLA ECAUDATA}

The sex of $A$. ecaudata could nearly always be determined by examination of the gonads. Those of the male are sac-like and only slightly lobed, while those of the female are divided into a large number of long narrow lobes (Ashworth, I9I2). Even when empty of gametes or very small the gonads of the two sexes are different in shape.

In the male the first sign of development is the appearance of balls of spermatogonia in the gonads. These balls flatten into discs and develop tails before being shed into the coelom (Downing, I9II). The tailed discs remain in the coelom for some time; occasional worms were taken in which the spermatozoa were free, and some of these specimens spawned when handled. We do not know whether the discs always break up into spermatozoa before spawning.

In the female the oocytes were first visible in the ovaries at a diameter of about $8-17 \mu$. All were about the same size and seemed to develop at the same rate, while the gonad grew in size to accommodate them. The full ovaries usually filled the anterior part of the coelom. The oocytes developed a thick vitelline membrane at the same size as do those of $A$. branchialis (about $0.12 \mathrm{~mm}$ ). They were sometimes shed into the coelom at this stage, but were usually retained until they had reached $0.137-0.15 \mathrm{~mm}$. Once in the coelomic fluid they continued to grow in size until they were about $0.17 \mathrm{~mm}$ in diameter (stage Io).

In the male a few tailed discs or free spermatozoa remained in the coelom after spawning. In the female the coelom was completely empty of oocytes after spawning; the gonads of recently spent worms could easily be distinguished from early development stages by their large size and flabby condition.

\section{Annual cycle}

The results of 2 years' sampling of the Church Reef population are shown in Fig. 3, together with I year's results from the West Reef and Drake's Island populations. The two Wembury populations are shown separately, unlike those of $A$. branchialis, not only because the samples were sufficiently large, 
but because there seems to be some difference between them. The small specimens have been omitted from the figure, on and after 15 November 1955, as with $A$. branchialis. Before this date the classification 'sex unknown' probably included small undeveloped worms as well as spent and empty adults.

At all three sites, Church Reef, West Reef and Drake's Island, mature males of $A$. ecaudata were present practically all the year round. It is difficult to determine any definite cycle, although the least proportion of such males was found in late winter, the greatest in summer. This trend is best shown by the West Reef samples. From the minimum in January and February 1956,

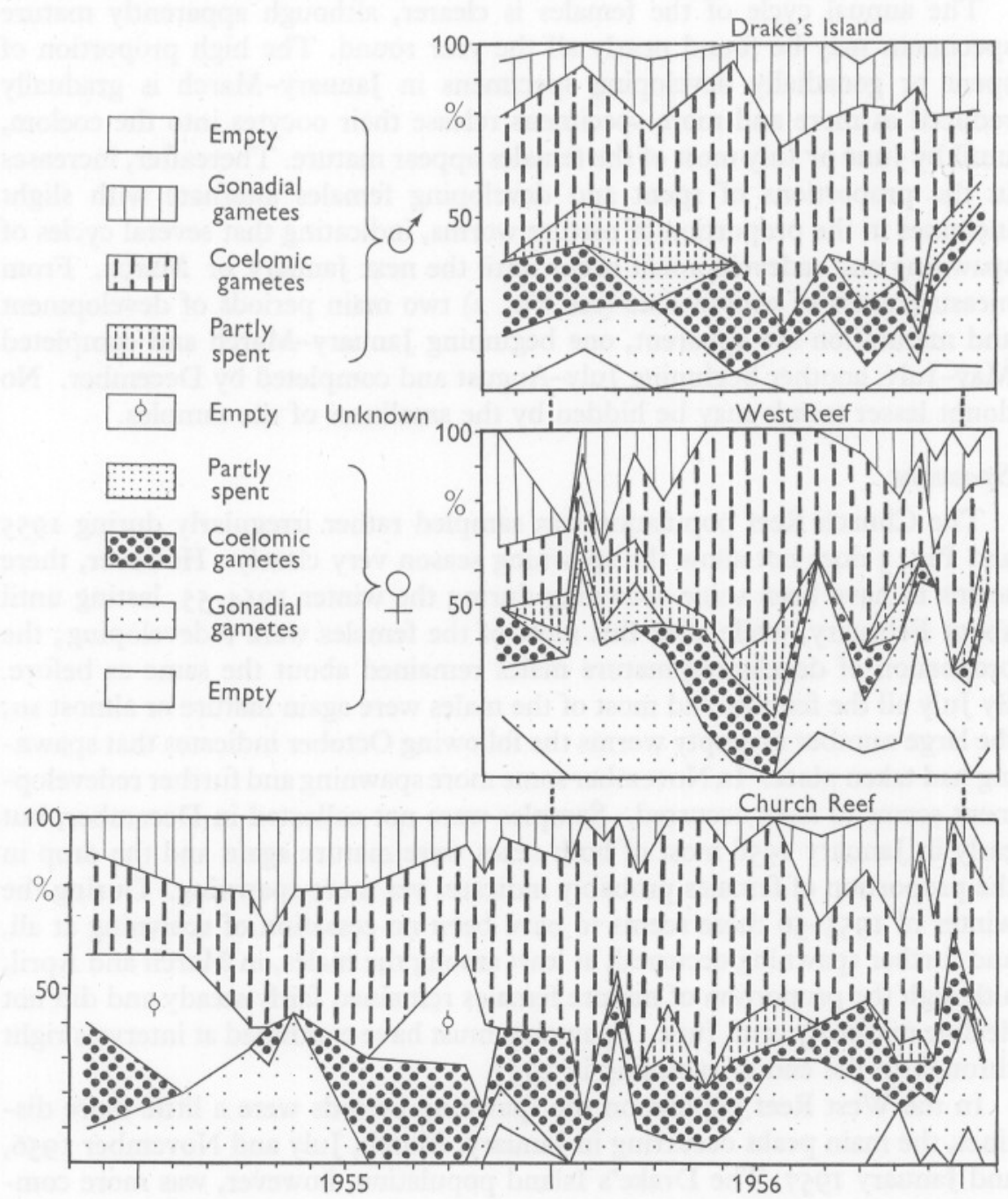

Fig. 3. Arenicola ecaudata. Percentages of breeding stages in samples from three localities. 
when most of the males were either spent or developing gametes in the gonads, the number with coelomic gametes increased steadily to May, when over half the samples consisted of mature males. The proportion declined from June to August and at the same time the proportion of spent males increased. There was another increase in mature males up to September, after which the proportion declined, most of the males being in the gonad developing condition. A further peak of mature males occurred in December 1956, followed by another decline in January 1957. This suggests that several spawnings occurred during the year.

The annual cycle of the females is clearer, although apparently mature specimens may be found nearly all the year round. The high proportion of spent or gonadially developing specimens in January-March is gradually reduced as more and more specimens release their oocytes into the coelom, until by June or July most of the females appear mature. Thereafter, increases in the proportions of spent and developing females alternate with slight increases in the proportion of mature worms, indicating that several cycles of spawning and redevelopment occur until the next January or March. From measurements of oocyte sizes (see Fig. 2) two main periods of development and maturation are apparent, one beginning January-March and completed May-July, another beginning July-August and completed by December. No doubt lesser trends may be hidden by the smallness of the samples.

\section{Spawning}

The Church Reef population was sampled rather irregularly during 1955 and Fig. 3 does not show the spawning season very clearly. However, there seems to have been some spawning during the winter 1954-55, lasting until about February, while after this most of the females were redeveloping; the proportion of developing/mature males remained about the same as before. By July all the females and most of the males were again mature or almost so; the large number of empty worms the following October indicates that spawning had taken place. In November some more spawning and further redevelopment seems to have occurred. Samples were not collected in December, but early in January 1956 most of both sexes were mature again and the drop in the proportion of females probably indicates yet more spawning. During the winter of 1955-56 there seems to have been no cessation of spawning at all, and further spawning occurred, at least among the males, in March and April, although the proportion of mature females remained fairly steady and did not decline markedly until June. Spawning must have continued at intervals right through to the end of sampling in 1957.

In the West Reef population the spawning periods were a little more distinct, the main peaks occurring in January, March, July and November 1956, and January 1957. The Drake's Island population, however, was more comparable to that of Church Reef, in that spawning seemed continuous, although 
the main peaks were indicated by the presence of spent females in the samples.

It is worth noting that, in general, the deposit at the Church Reef and Drake's Island sites was richer in decaying sea-weeds and other organic matter than that at West Reef. The average size of the worms was greater at these two sites, and it is possible that the apparently continuous breeding activities there may have been due to the presence of more abundant food.

\section{Effect of parasites}

Two sporozoan parasites have been recorded from Arenicola ecaudata at Plymouth (Cunningham, I907; Goodrich \& Pixell-Goodrich, 1920), and both were found again during the present survey.

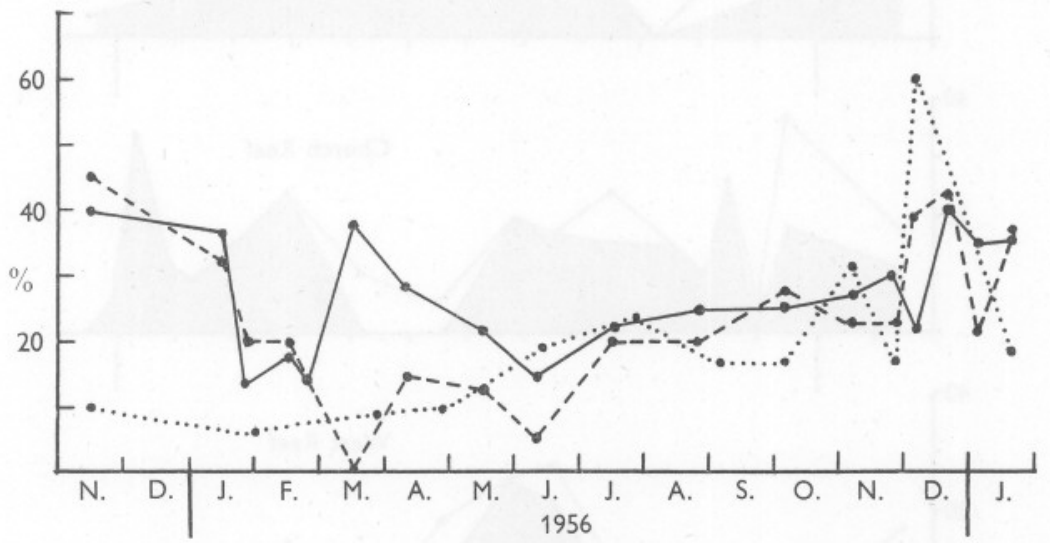

Fig. 4. Percentage Arenicola ecaudata containing cysts of Gonospora arenicolae, in each sample from three localities: ——, Church Reef; - - - , West Reef; ...., Drake's Island.

The trophozoites of Gonospora arenicolae (Cunningham) live attached to the nephridia of both sexes of Arenicola ecaudata, dropping off into the coelomic fluid when mature and uniting in pairs or in groups to form gametocysts (Cunningham, I907). These cysts are white spheres, about $\mathrm{I} \mathrm{mm}$ in diameter, and obvious to the unaided eye. We did not examine the nephridia of every specimen but believe that most were infected with trophozoites (cf. Hentschel, I930). We recorded the presence of gametocysts in the coelom and show in Fig. 4 their occurrence during 1956. There was a winter maximum in all three populations, coinciding more or less with the winter spawning. In the Church Reef population there was a second peak in March, just before the April spawning (see Fig. 3), but in the others there was a steady rise in rate of occurrence from February to November, with a rapid rise about December. Except in a few cases of extremely heavy infection, when the coelom was almost full of trophozoites and cysts, this parasite did not apparently affect the 
rate of development of the gametes, although, by using part of the available food supply, it must have reduced their numbers.

Gonospora minchini Goodrich \& Pixell-Goodrich has trophozoites which attack the oocytes of Arenicola ecaudata, entering them sometime after they have been released from the gonads. The growing trophozoite enlarges the oocyte membrane enormously and destroys its contents. The trophozoites emerge from the membranes when full grown and unite in pairs or groups, as

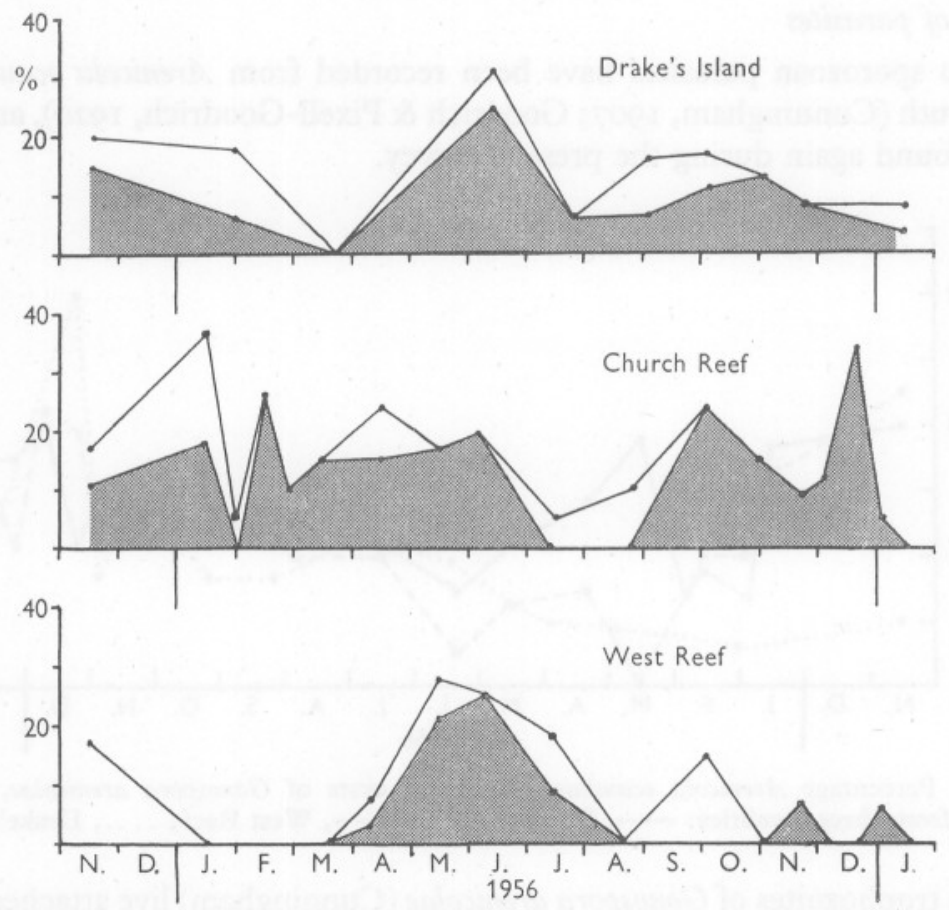

Fig. 5. Percentage Arenicola ecaudata containing coelomic oocytes in each sample from three localities. Percentage infected with Gonospora minchini stippled.

in Gonospora arenicolae. They form cysts which are, to us, indistinguishable from those of $G$. arenicolae. Since both parasites may be present in one worm, some of our records of $G$. minchini in the gametocyst stage may include $G$. arenicolae and vice versa.

G. minchini apparently never attacks the oocytes while they are in the ovaries. We have not been able to discover whether there is some other site of infection in the worm during the development of the ovaries, but well over $50 \%$ of the worms with coelomic oocytes had this parasite in them. Fig. 5 shows the proportion of these females infected in each sample during 1956. Some of these were only lightly infected (I-10\% of the oocytes attacked) but others had up 
to $50 \%$ of the oocytes destroyed. Though the presence of the parasite does not appear to affect the rate of development of the unattacked oocytes, it has a marked effect on the fecundity of the host.

\section{Larval development}

On two occasions (16 November 1954 and 2 November 1956) specimens of Arenicola ecaudata spawned in the laboratory and produced fertilized eggs, a few hours after the samples had been brought in from the shore. Hentschel (1930) noted that the worms spawned inside their transparent tubes, moving about as they poured out their genital products. We found the eggs embedded in these transparent tubes, which the worms always form when kept in the laboratory. The tubes, after being washed, were placed in finger bowls of filtered sea water and kept at a temperature of approximately $15^{\circ} \mathrm{C}$.

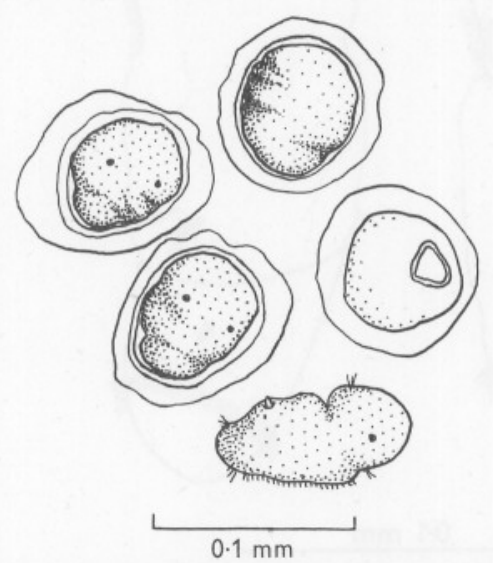

Fig. 6. Arenicola ecaudata. Group of larvae ready to hatch; with one already hatched and an empty egg membrane.

In the first case hatching was not observed, but the larvae were crawling about the dish on the eighth day. In the second case hatching took place on the eighth day, and before hatching the larvae were seen to twist about inside the egg membrane for some time. They finally emerged through a small hole (Fig. 6), crawled about the bottom of the dish and formed small transparent tubes; they were not seen to swim at any time.

The newly hatched larva (Figs. 6, 7A) had two circular bands of cilia with a ventral band between them (as in A. marina (Newell, 1948)), a pair of dorsal limbate setae and a pair of red eye-spots with dorsal lenses. During the next 2 or 3 days a second notoseta and an uncinate neuroseta appeared on each side; these were followed by the first limbate notosetae of the second setigerous segment (Fig. 7B). Table 3 shows the rate of development of the larvae. The second and third setigers developed in the same way as the first, but after this 
the first notoseta to appear on each side was uncinate and the limbate setae developed later (Table 4 ; Fig. 7C); this also occurs in other species of Arenicola (Ashworth, I912).

The I954 larvae developed only to the 4 -setiger stage, but lived a further I4 days without any more growth. The 1956 larvae reached the 6-setiger stage and lived a further 40 days without further growth or development, although various algal cultures (kindly supplied by $\operatorname{Dr} M$. Parke) were provided as food and were eaten by the larvae.

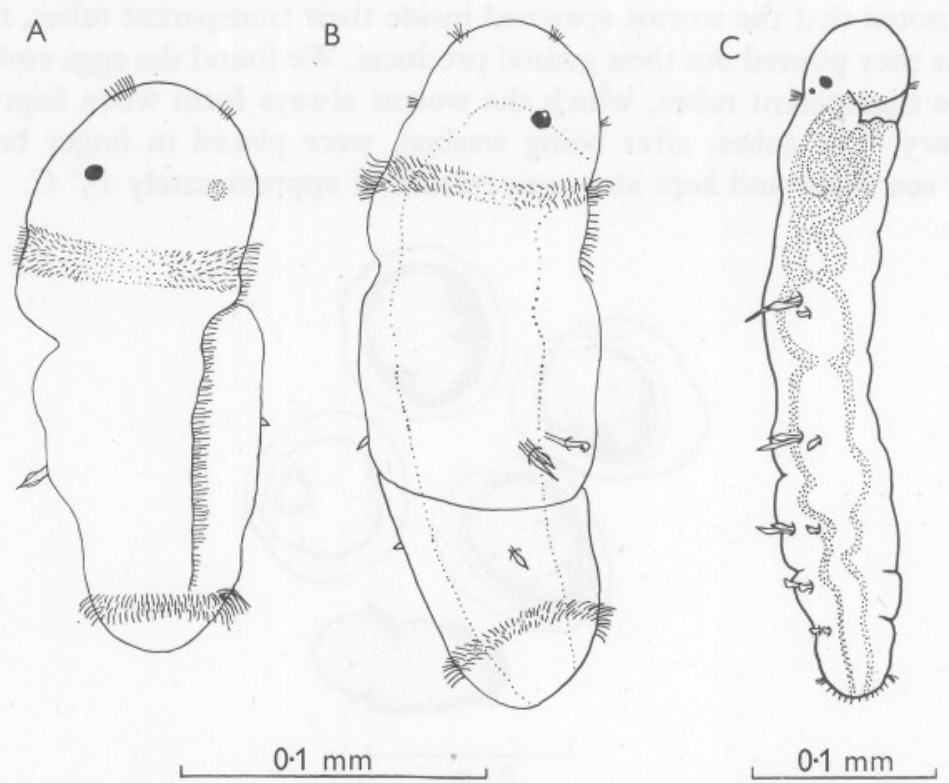

Fig. 7. Arenicola ecaudata. A, larva with one setigerous segment, showing ventral ciliated band; B, larva with two setigerous segments, side view; c, larva with five setigerous segments, side view (alimentary canal stippled). From camera lucida drawings of living larvae.

\section{Behaviour of larvae}

The larvae started feeding at the 4 -setiger stage when the gut was completely formed and the mouth and anus open. The pharynx was ciliated and not yet eversible, though it was capable of some movement. The food taken was bacteria and small fragments of detritus, the remains being ejected as faecal pellets about $34 \times 17 \mu$. A second pair of eyespots appeared, and, as the 5 th setiger developed, yellow pigment was laid down in the prostomium, around the anus, and in the wall of the mid-gut. The proboscis grew larger and became eversible. By the 6-setiger stage it was well developed, and the larvae were feeding actively, picking up bacteria, algae and detritus from the bottom of the dish. The proboscis was everted in two stages, as shown in Fig. 8. By this time the larvae had developed a fairly definite pattern of behaviour, which 
consisted basically of backward and forward movements in the tube, which was about twice the length of the larva. When watched under the microscope, at $15-20^{\circ} \mathrm{C}$, the larva moved back and forth once or twice a minute.

TABLE 3. RATE OF DEVELOPMENT OF ARENICOLA ECAUDATA LARVAE

\begin{tabular}{lrrr}
$\begin{array}{l}\text { Date of fertilization } \\
\text { Stage reached }\end{array}$ & 16. xi. 54 & 2. xi. 56 \\
Hatching (I-setiger) & \multicolumn{2}{c}{ Age in days } \\
2-setiger & II & 10 \\
4-setiger & & I7 & 20 \\
5-setiger & & - & 28 \\
6-setiger & & 34
\end{tabular}

TABLE 4. SETAE OF 6-SETIGER LARVA OF ARENICOLA ECAUDATA

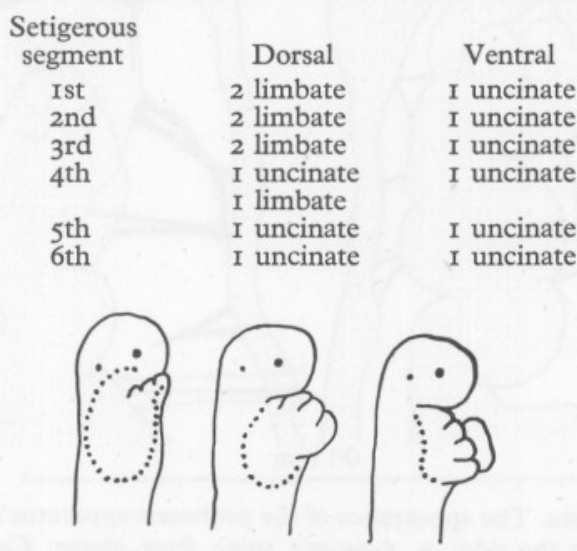

Fig. 8. Arenicola ecaudata. Two stages in eversion of the proboscis in a 6-setiger larva. Sketches of living larva.

During feeding the proboscis was extruded at the end of a forward movement, and there were up to twenty of these extrusions, at the rate of five to ten per minute, before the larva moved back. The next forward movement was followed by further extrusions of the proboscis, and so on for up to $15 \mathrm{~min}$. Between periods of feeding activity there were periods of back and forth movement alone, lasting an hour or more, during which one or two faecal pellets were produced. Each of these was ejected at the end of a backward movement so that a heap of faecal pellets was built up a short distance behind each larva. The larvae would occasionally turn round in the tube and continue the same behaviour facing the other way.

\section{Proboscis apparatus of the larva}

The origin of the retractor sheath and gular membrane, or 'first diaphragm', of Arenicola has been the object of some speculation; in the adult the two structures are associated at their junction with the body wall and, while 
Lillie (1905) considered that they originated separately, Wells (1952, 1954) suggested that they were derived from the splitting of a single septum. We have examined stained specimens of I-, 2-, 4- and 5-setiger larvae of A. ecaudata, and find that in the last two of these the gular membrane and retractor sheath are already separate, although the membrane has not yet assumed its adult

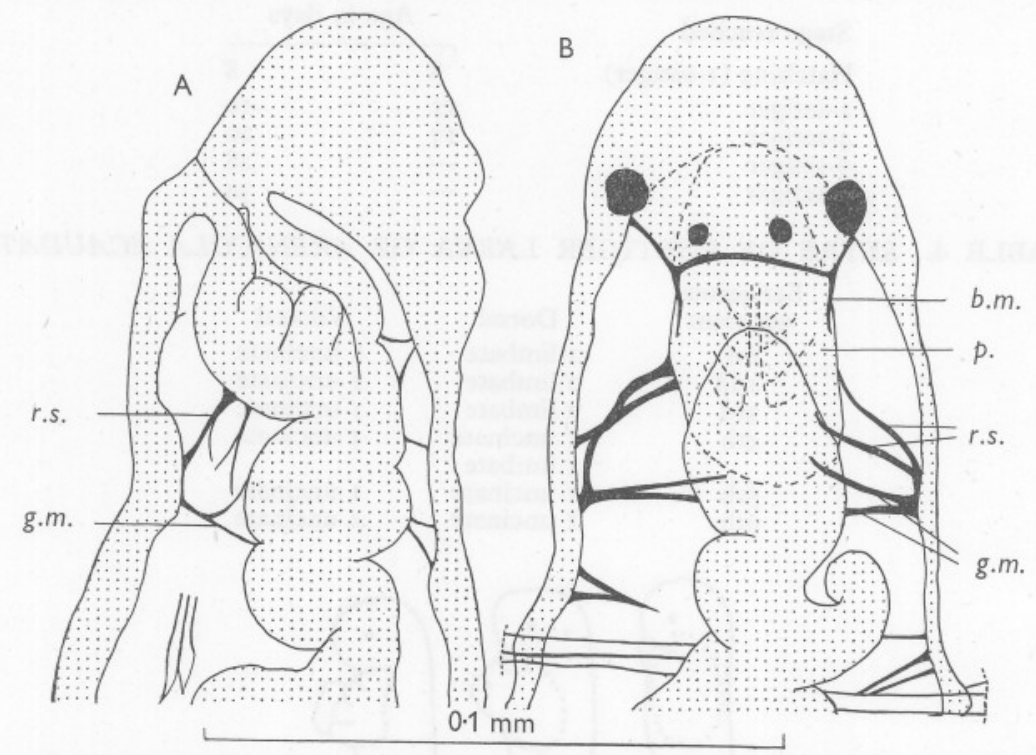

Fig. 9. Arenicola ecaudata. The appearance of the proboscis apparatus in stained whole larvae A, 4-setiger stage, from the side; B, 5-setiger stage, from above. Camera lucida drawings. b.m., buccal membrane; g.m., gular membrane; r.s., retractor sheath; p., pharynx.

form (Fig. 9). The I- and 2-setiger larvae are rendered opaque by the yolk they contain. Any splitting of the larval septum must take place before the 4-setiger stage; to show it clearly, horizontal sections of the larvae would probably be required.

\section{Later development}

The post-larval and juvenile stages of $A$. ecaudata can be found towards L.w.s. among small algae and in Laminaria holdfasts. Ashworth (I9I2) recorded them from Ireland in September and McIntosh (1915) found them in the Hebrides in August. We have found juveniles (less than $2 \mathrm{~cm}$ long) in the Isle of Man in the following months: January, March, April, May, July, August and September. We have found them at Plymouth in October but have not looked for them at other times of the year.

The smallest specimens found in the adult habitat at Plymouth were 2-3 cm in length and had a volume of $\mathrm{I} \mathrm{ml}$. or less. These occurred in our samples throughout the year. 


\section{COMPARISONS AND CONCLUSIONS}

Having described the breeding cycles of Arenicola ecaudata and A. branchialis, we can compare them with one another and with those of other species. The absence of resting phases from these cycles distinguishes them both from that of $A$. marina, the only other species thoroughly investigated (Newell, I948).

In spawning habits $A$. ecaudata resembles most closely the Japanese A. claparedii (Okuda, I938), although the breeding cycles are not very similar. The larvae of $A$. ecaudata are slow to develop, in comparison with those of other species of Arenicola, but the larvae of all species are otherwise very much alike.

The breeding cycles of animals and plants are usually dependent in some way on annual fluctuations in external conditions, particularly temperature and food supply (Orton, I920; Thorson, I946; Qasim, 1956; Crisp \& Southward, 1958). At Plymouth the same temperature régime is experienced by both $A$. ecaudata and $A$. branchialis and the same food supply is available to each. The amount of algal detritus on the shore varies considerably with the weather conditions, but even when it is at its lowest it is still abundant in the habitat of these species, though branchialis can apparently tolerate a lower organic content than can ecaudata (p. 268). It appears that the food supply should always be sufficient, and so we must look to temperature for an explanation of the difference between their breeding cycles.

According to Orton (1920), cosmopolitan species should have a wide range of temperature within which breeding can occur; cold-water species near their warmer limits should breed in the colder months of the year; warm-water species near their colder limits should breed in the warmer months of the year. Many organisms have been shown to conform to these conditions, but the two ecaudate species of Arenicola do not.

The temperature requirements of any species vary during its life history and during its breeding cycle. The geographical distribution may be closely linked to the temperature tolerance of the adult, but the breeding cycle is affected by different temperatures at each stage and this also may affect the distribution of a species. A. branchialis is nearing its northern limit at Plymouth and if it is limited by low temperature and not by any other factor then this may take effect in one or more of the following ways. A lower winter temperature than that normally experienced on the west coasts of the British Isles may kill the adults. Since the gonads are capable of initiating gamete production during the coldest part of the year at Plymouth it seems unlikely that gametes could not be produced, in the warmer months at least, further north; however, growth and maturation of the gametes are slow at Plymouth, taking up to Io months. Further north maturation might not be completed in the shorter summer. Spawning takes place at Plymouth as the sea temperature is falling, and the larvae must develop during the coldest part of the year; 
farther north lower temperatures on the shore might be lethal to the larvae, if not to the adults. The distribution of branchialis south of the Mediterranean area is presumably limited by the effect of high winter temperatures on the spawning or the larvae, but little is known of the breeding cycle there.

A. ecaudata is nearing its southern limit at Plymouth but it extends further north than branchialis. Since gametes can be produced and matured all the year round at Plymouth, these processes should take place at least in the warmer months in the northern, and in the colder months in the southern part of its range. Both sexes apparently spawn at all times of year at Plymouth, and presumably larvae are produced, so a wide range of temperatures should be suitable for development. If low winter temperatures were lethal to larvae further north the spring and summer larvae should still be able to survive. Similarly, further south, the winter-spawned larvae ought to be able to survive. Thus, the northern limit of this species would appear to depend on the effect of low winter temperature on the adults, but there seems little reason for the position of the southern limit. As far as the breeding cycle is concerned ecaudata could presumably extend as far south as branchialis.

Other species of Arenicola do not show very clear correlation between breeding habits and geographical distribution; A. marina is a cold-water species which does spawn in the colder months of the year, near its warmer limits (Newell, 1948; Duncan, 1950), but $A$. claparedii, another cold-water species, appears to develop during the cold months and spawn in spring or early summer (Ashworth, 1912; Guberlet, 1934; Okuda, 1938). A. cristata is a warm-water species which spawns in summer in the cooler parts of its range, though the gametes develop throughout the winter (Downing, I9II). This suggests a breeding cycle rather like that of $A$. branchialis, with spawning a few months earlier. In the tropics, spawn of $A$. cristata has been reported at various times of the year (Okuda, 1938; Takahashi, 1938; Bhatti \& Soofi, 1949), which suggests that, like many tropical animals, $A$. cristata may breed all the year round. Information on the breeding of the remaining species of Arenicola is not sufficient for comparison with their distribution.

Before we can come to any definite conclusions we need to know more about the breeding of all the species of Arenicola. Temperature can be only a partial cause of the limited distribution of $A$. ecaudata. The limits of $A$. branchialis seem, however, to show the effect of temperature on various stages of the life cycle. The boundary between these two species might be affected by the influence of temperature on competition between them. Although ecaudata is commoner than branchialis at Plymouth, the latter maintains itself by a short spawning period compared with the almost continuous spawning of ecaudata.

The effect of parasites must also be considered; it is possible that increasing temperature might favour the species of Gonospora at the expense of their host and that farther south $A$. ecaudata might be rendered completely sterile by heavy infections of these sporozoans. 
From anatomical evidence Ashworth (I9I2) considered A. ecaudata to be the species of Arenicola nearest the ancestral form, and perhaps the most ancient of the existing species. If this be so, its geographical range might have been wider in the past and have become restricted by competition, parasites or other causes, in comparatively recent times.

\section{SUMMARY}

The two 'tail-less' lugworms, Arenicola ecaudata and A. branchialis, live in gravel and under stones, on the shores of western Europe. A. ecaudata has a more boreal range than $A$. branchialis, but both have a restricted geographical range compared with the remaining species of Arenicola, which live in sandy beaches.

At Plymouth $A$. branchialis is a winter-spawning species. Development of the gametes continues through spring, summer and autumn, and spawning apparently occurs over 4-6 winter months, usually November to February.

A. ecaudata, on the other hand, apparently spawns all the year round, mature males and females being found in all months. In 1954 and 1955 there was a fairly definite breeding cycle, with development of gametes in spring, followed by several periods of spawning and redevelopment until the end of the following winter. There seems to have been no cessation of spawning at all in the early spring of 1956; periods of redevelopment and spawning were practically continuous from winter $1955-56$ to winter $1956-57$.

Only $A$. ecaudata is infected with sporozoan parasites, which frequently reduce its fecundity.

Larval development of $A$. ecaudata was followed up to the appearance of the 6th setigerous segment, when the adult pattern of behaviour was already beginning to appear.

The distribution of $A$. branchialis may be controlled by the effect of temperature on various stages of the life cycle. The northern limit of $A$. ecaudata can likewise be explained by temperature limitation, but the restricted southern limit may be due to effects of competition, parasites or other causes; it is apparently not due to a direct effect of temperature on the breeding cycle.

\section{REFERENCES}

Ashworth, J. H., 1912. Catalogue of the Chaetopoda in the British Museum. A. Polychaeta: Part I-Arenicolidae. London: British Museum.

Bhatti, H. K. \& Soofi, M., 1949. Arenicola-a polychaete from Karachi. Pakist. F. Sci., Vol. I, pp. 76-7.

BIANCO, S. Lo, I909. Notizie biologiche riguardanti specialmente il periodo di maturità sessuale degli animali del golfo di Napoli. Mitt. zool. Sta. Neapel, Bd. I9, pp. 513-761.

BRUCE, J. R., I928. Physical factors on the sandy beach. Part II. Chemical changescarbon dioxide concentration and sulphides. F. mar. biol. Ass. U.K., Vol. 15, pp. 553-65. 
CRISP, D. J. \& SouthwARD, A. J., I958. The distribution of intertidal organisms along the coasts of the English Channel. F. mar. biol. Ass. U.K., Vol. 37, pp. 157-208.

CuÉnot, L., I891. Infusoires commensaux des Ligies, Patelles et Arénicoles. Rev. biol. N. France, T. 4, pp. 81-9.

CunNingham, J. J., I907. On Kalpidorhynchus arenicolae, a new gregarine, parasitic in Arenicola ecaudata. Arch. Protistenk., Bd. I0, pp. I99-215.

DownING, E. R., 1909. The connections of the gonadial blood vessels and the form of the nephridia in the Arenicolidae. Biol. Bull., Woods Hole, Vol. I6, pp. $246-58$.

- I9II. The formation of the spermatophore in Arenicola and a theory of the alternation of generations in animals. F. Morph., Vol. 22, pp. 100I-43.

Duncan, N., 1950. Spawning of Arenicola marina L. in captivity. Rep. mar. biol. Sta. Pt Erin, No. 62, pp. 27-9.

Fauvel, P., I899. Observations sur l'Arenicola ecaudata Johnston. Bull. Soc. Linn. Normandie, Ser. 5, Vol. 2, pp. 3-32.

- 1927. Polychètes sédentaires. Faune Fr., No. 16, 494 pp.

GoODRICH, E. S. \& PIXELL-GoodRICH, H., I920. Gonospora minchini n.sp., a gregarine inhabiting the egg of Arenicola. Quart. F. micr. Sci., Vol. 65, pp. 157-62.

GUBERLET, J. E., 1934. Observations on the spawning and development of some Pacific annelids. Proc. Pacif. Sci. Congr., Vol. 5, pp. 4213-20.

HentsChel, C. C., I930. On the correlation of the life-history of the acephaline gregarine, Gonospora, with the sexual cycle of its host. II. Gonospora (Kalpidorhynchus) arenicolae. Parasitology, Vol. 22, pp. 505-9.

LILlIE, R. S., I905. The structure and development of the nephridia of Arenicola cristata Stimpson. Mitt. zool. Sta. Neapel, Bd. 17, pp. 34I-405.

McIntosh, W. C., I9I5. A Monograph on the British Marine Annelids, Vol. 3, $368 \mathrm{pp}$. London: Ray Society.

NewELl, G. E., I948. A contribution to our knowledge of the life history of Arenicola marina L. F. mar. biol. Ass. U.K., Vol. 27, pp. 554-80.

OKUDA, S., I938. Notes on the spawning habit of Arenicola claparedii Levinsen. Annot. zool. jap., Vol. 17, pp. 577-80.

ORton, J. H., I920. Sea-temperature, breeding and distribution or marine animals. 7. mar. biol. Ass. U.K., Vol. I2, pp. 339-66.

QASIM, S. Z., I956. Time and duration of the spawning season in some marine teleosts in relation to their distribution. F. Cons. int. Explor. Mer, Vol. 21, pp. I44-55.

Rioja, E., 1935. Annelidos poliquetos procendentes de la campañas del Instituto Español de Oceanografio. Trab. Inst. esp. Oceanogr., No. 13, 44 pp.

Southern, R., I9I4. Archiannelida and Polychaeta. Clare Island Survey. Proc. R. Irish Acad., Vol. 31, Sect. 2, Pt. 47, I60 pp.

TAKAHASHI, K., 1938. On some castings of sand in Korror Island of the Palao group. Palao trop. biol. Stud., Vol. I, pp. 459-68.

Thorson, G., I946. Reproduction and larval development of Danish marine bottom invertebrates, with special reference to the planktonic larvae in the Sound (Øresund). Medd. Komm. Havundersøg., Kbh., Ser. Plankt., Bd. 4, No. I, 523 pp.

Wells, G. P., 1952. The proboscis apparatus of Arenicola. F. mar. biol. Ass. U.K., Vol. 3I, pp. I-28.

- 1954. The mechanism of proboscis movement in Arenicola. Quart. F. micr. Sci., Vol. 95, pp. 25I-70.

Wesenberg-Lund, E., 195I. Polychaeta. Zool. Iceland, Vol. 2, Pt. 19, I82 pp. 